\title{
Global Forestry Perspective: COVID-19 Impact and Assessment
}

\author{
Maneesh S. Bhandari $^{1}$ (D) Shailesh Pandey $^{2} \cdot$ Aman Dabral $^{1} \cdot$ Rajendra K. Meena $^{1}$. \\ Rama Kant ${ }^{1}$
}

(C) The National Academy of Sciences, India 2021

\begin{abstract}
Corona virus disease 2019 (COVID-19) caused by corona virus SARS-CoV-2 is believed to be originated in Wuhan province of China, which has spread all over the world. It has severely impacted the social, cultural, educational, research and development programmes throughout the globe. Since the inception of various lifeforms on planet earth, forests' plays an important role in the evolutionary history of organisms and fitness persuades the existence of modern-day species in different ecosystems. The visible effect of pandemic leads to the lockdown with positive implications on the earth biosphere as a whole; while on other hand, lockdown seized and reduced the urbanization and developmental projects, especially the research and development progress in the field of forestry and allied sciences. This viewpoint addresses key questions and point-out with detailed exploration of the problem as how COVID-19 pandemic impacts forestry research all over the world? We also suggest possible solutions, and
\end{abstract}

Maneesh S. Bhandari

maneesh31803@gmail.com

Shailesh Pandey

shailesh31712@gmail.com

Aman Dabral

amandabra193@gmail.com

Rajendra K. Meena

rajnrcpb@gmail.com

Rama Kant

rgpb82@gmail.com

1 Division of Genetics \& Tree Improvement, Forest Research Institute, Dehradun 248 195, Uttarakhand, India

2 Forest Pathology Discipline, Division of Forest Protection, Forest Research Institute, Dehradun 248 006, Uttarakhand, India define the role and association of disciplines, such as bioinformatics, remote sensing and statistical modules along with previously explored and collected field data as a sustainable measure to resolve the problems of forestry sector of this mighty challenge.

Keywords COVID-19 · Forestry · Pandemic · Remote sensing $\cdot$ Bioinformatics $\cdot$ Statistical module

\section{Significance Statement}

Pandemic caused by COVID-19 has serious implications on forestry research across the globe. We highlighted the effect of ongoing pandemic and lockdown issues in relation to field-based sampling and data collection in forest-based ecosystems. There is a need to associate forestry research with bioinformatics, geoinformatics and spatio-temporal statistics to make progress in scientific research-base of forestry to answer future pandemic threats.

\section{Views}

It has been since December 2019, the world was stand still in year 2020 due to COVID-19 pandemic causing survival challenges to eugenics [1,2]. When the people were watching the Women's World Cricket at Australia in January 2020, and waiting for the forthcoming Tokyo Olympics and T20 World Cricket [3, 4]; the things fell apart as un-knitted wool. However, some interesting things were also experienced as positive consequences of global lockdown; for instance, a significant improvement in air quality and the everlasting beauty of Himalayas, such as Gangotri glacier were visualised from far-flung areas of Jalandhar 


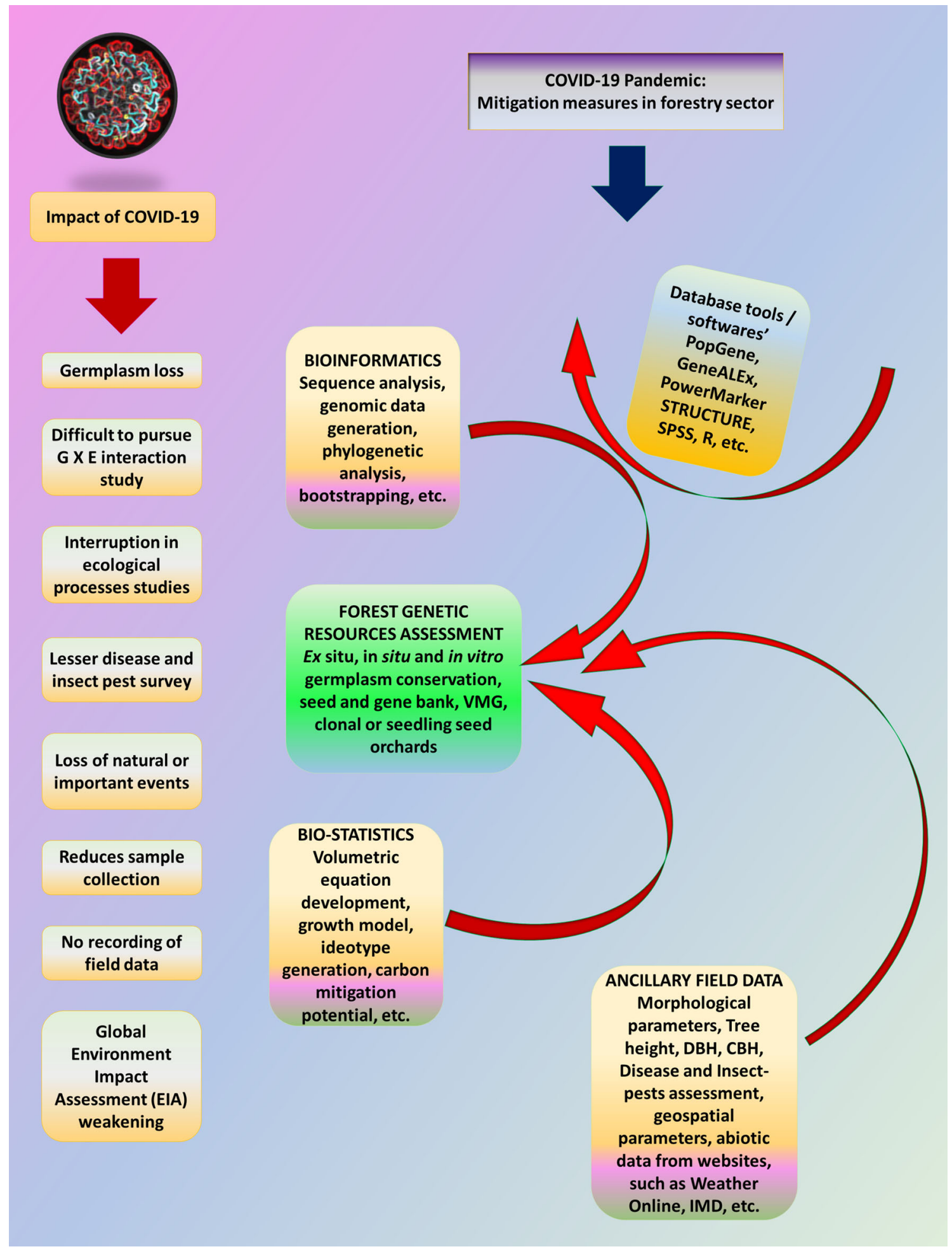

Fig. 1 Illustration depicting forestry research affected by COVID-19 pandemic and its possible mitigation measures

and Saharanpur (India), and Great Mount Everest from Kathmandu (Nepal) [5-7]. Nonetheless, the environment gets the benefits of the lockdown, though humanity has been under stress in the last 17 months or so. The global lockdown imposed to control COVID-19 spread, which has severely impacted the economies of many countries ( https://www.wto.org/english/news). Although before pandemic, the urbanization and expansion deeds of human led to the accomplishments of developmental targets at the expense of nature. These repercussions remind us of the 
resilient nature of our forests', when severe burn scar is deepened its trouble during fire incidences, for instance Australian bush fire during 2019, where millions of precious and endemic vegetation and faunal life gets destroyed [8]. Unimaginably, during an unprecedented event of rainfall, flash floods and cloudbursts, the forests again play a crucial role of humanitarian survival and support $[9,10]$. These selfless goals are only propagated in nature, until humans detrimentally exploit them. The impact of COVID19 consequences could be largely seen worldwide on the routine forestry research [11] (Fig. 1). Prominently, the loss of precious genetic ravines might occur each year, if a particular species improvement programme is discontinued [12]. Further, the on-field experimentation requires ecological artefacts and observations from ecosystems, which will be unable to persuade without coming into contact with nature [13]. The disciplines, such as forest dynamics and hydrology dealt with studying stand structure, species composition, spatio-temporal variations, over and under surface water assimilation, etc. [14]. However, the aftermath to meet these paradigms are quite complicated in deficit of the on-field data. Ironically, the basic need of field-oriented programs are periodic sample collection and data recording, which could not be performed for the spring equinox and pre-monsoon regime of year 2020 and 2021. If we think after all these crises, the biodiversity will be naturally conserved and there is no need for further investigation; then again, we indulge ourselves into the same harmony where the COVID-19 originates.

Conservation of biodiversity requires raw data for monitoring the current state of forest and quantifying the influence of prevailing biotic and abiotic factors. Since most field activities remain suspended, the highly sophisticated computational analysis and programming work has been in peak since February 2020 for drug designing against COVID-19. Similarly, forestry research could also be invigorated using advance tools and techniques. Many researchers highlighted the potential of satellite-based Remote Sensing and Geographical Information Systems (RS \& GIS) to collect and disseminate the data on forestbased resources. Using RS \& GIS tools, users may gather the geographical features or data for the study sites which are unreachable and inaccessible for ground-based sampling. Notably, the phenology and seasonal changes for gregariously distributed species could augur and prosper fully, if earlier data on species existence is available with the user [15]. Again, with scattered and fragmented species, the hyperspectral RS and radio waves-based satellite images might enhance the biogeographical prediction and volumetric estimation [16]. Noteworthily, the migration biology of fungal spores and insect-pests could be determined based on the previous experience of field observation and secondary data generated from geoinformatics- based maps [17]. Furthermore, in case of forestry tree species, the morphological field data could be used to develop correlation / regression-based statistical models for estimation of biomass and carbon sequestration potential ${ }^{18}$. The realized gain of RS \& GIS technology is pertinent in the tree improvement programmes, where the field experiments laid earlier need to be evaluated for heritability and other genetic parameters estimates. The statistical models could be developed for the actual trait performance using satellite imagery and ground-based verification. Inherently, the observations recorded during the earlier field experience would now be better utilized to generate statistical models on growth performance parameters of a species (Fig. 1). The bioinformatics-based computational analysis is another field which remained unaffected due to pandemic, and therefore, this is an opportunity to boost the in silico research in forestry.

Acknowledgements The financial support by the Ministry of Environment, Forest and Climate Change (MoEF\&CC), Government of India, New Delhi under project No. 75 / 2019 / ICFRE (R) / RP / SFRESPE (CAMPA) / AICRP-24 / Main File /43, dated 10/01/2020 is gratefully acknowledged. The authors are thankful to the Director, FRI, Dehradun for providing the research facilities.

Authors Contributions MSB conceived the research ideas, wrote the first draft of the manuscript, generate illustration and led the writing. SP, AD, RKM, and RK edited the draft and provide suggestions. All authors critically revised the manuscript.

Funding Ministry of Environment, Forest and Climate Change (MoEF\&CC), Government of India, New Delhi under project No. 75 / 2019 / ICFRE (R) / RP / SFRESPE (CAMPA) / AICRP-24 / Main File /43, dated 10/01/2020.

Data Availability All data files have been uploaded and clearly written in the manuscript.

\section{References}

1. McIntosh K, Hirsch MS, Bloom A (2020) Corona virus disease 2019 (COVID-19). Disponívelem: https://www.uptodate.com/ contents/coronavirus-disease-2019-covid-19-epidemiology-viro logy-clinical-features-diagnosis-and-prevention

2. WHO (2020) Corona virus disease 2019 (COVID-19): Situation Report 2020

3. BBC (2020) Corona virus: How the virus has impacted sporting events around the world. https://www.bbc.com/sport/51605235

4. Cooper JA, Alderman DH (2020) Cancelling March Madness exposes opportunities for a more sustainable sports tourism economy. Tour Geog. https://doi.org/10.1080/14616688 .2020 .1759135

5. Kumari P, Toshniwal D (2020) Impact of lockdown on air quality over major cities across the globe during COVID-19 pandemic. Urban Climate 34:100719. https://doi.org/10.1016/j.uclim.2 020.100719

6. Nongrum D (2020) COVID-19 Lockdown effect: Saharanpur glimpses Himalayan peaks after 30 years due to clear sky. https://www.india.com 
7. Singh R (2020) After several decades, Mount Everest visible from Kathmandu as Covid-19 lockdown reduces pollution. https://www.india.com

8. WWF (2020) Statement from WWF-Australia on Australia's bushfire emergency. by WWF-Australia CEO, Dermot O'Gorman. https://www.wwf.org.au

9. FAO, CIFOR (2005) Forests and floods: drowning in fiction or thriving on facts? (Vol. 2). Centre for International Forestry Research. pp 1-30. https://www.cifor.org/publications/pdf_ files/Books/BCIFOR0501.pdf

10. Laurance WF (2007) Forests and floods. Nature 449:409-410. https://doi.org/10.1038/449409a

11. FAO (2020) The impacts of COVID-19 on the forestry sector: How to respond? PP 6. https://doi.org/10.4060/ca8844en

12. Johnson R, Clair BS, Lipow S (2001) Genetic conservation in applied tree breeding programs. In: Proceedings ITTO conference on in situ and ex situ conservation of commercial tropical trees. pp 215-230

13. Kitayama K, Fujiki S, Aoyagi R, Imai N, Sugau J, Titin J, Nilus R, Lagan P, Sawada Y, Ong R, Kugan F (2018) Biodiversity observation for land and ecosystem health (BOLEH): A robust method to evaluate the management impacts on the bundle of carbon and biodiversity ecosystem services in tropical production forests. Sustainability 10:4224. https://doi.org/10.3390/su10114 224
14. Julich S, Mwangi HM, Feger KH (2015) Forest hydrology in the tropics. In: Tropical Forestry Handbook, $2^{\text {nd }}$ Edn. pp 1917-1939. https://doi.org/10.1007/978-3-642-54601-3_152

15. Jonsson AM, Eklundh L, Hellström M, Barring L, Jönsson $P$ (2010) Annual changes in MODIS vegetation indices of Swedish coniferous forests in relation to snow dynamics and tree phenology. Rem Sens Environ 114:2719-2730. https://doi.org/10.10 16/j.rse.2010.06.005

16. Kumar L, Sinha P, Taylor S, Alqurashi AF (2015) Review of the use of remote sensing for biomass estimation to support renewable energy generation. J Appl Rem Sens 9:097696. https://doi.org/10.1117/1.JRS.9.097696

17. Gouli V, Gouli S, Marcelino JA, Skinner M, Parker BL (2013) Entomopathogenic fungi associated with exotic invasive insect pests in Northeastern forests of the USA. Insects 4:631-645. https://doi.org/10.3390/insects4040631

18. Zaki NA, Latif ZA, Suratman MN (2018) Modelling aboveground live trees biomass and carbon stock estimation of tropical lowland Dipterocarp forest: Integration of field-based and remotely sensed estimates. Interna J Remo Sens 39:2312-2340. https://doi.org/10.1080/01431161.2017.1421793

Publisher's Note Springer Nature remains neutral with regard to jurisdictional claims in published maps and institutional affiliations. 